\title{
Possible Association between Serum Hepcidin and Hemostatic Parameters in Chronic Renal Failure Rat Model: Influence of Inhibition of Angiotensin Converting Enzyme
}

\author{
MAHA A. FATHY, M.D. and NADINE A. RAAFAT, M.D. \\ The Department of Medical Physiology, Faculty of Medicine, Zagazig University, Egypt
}

\begin{abstract}
Background: Chronic renal failure (CRF) is usually associated with abnormal coagulation profile. Hepcidin is a major regulator of iron metabolism and was reported to have an impact on anemia, insulin resistance, dyslipidemia, inflammation and oxidative stress which were all reported to play a potential role in CRF induced coagulopathy. Renin angiotensin system (RAS) is involved in the pathophysiology of $\mathrm{CRF}$ and can affect coagulation profile.
\end{abstract}

Aim of Study: To evaluate changes in coagulation profile in a rat model of chronic renal failure and the possible association of these changes with serum hepcidin level in relation to some metabolic, inflammatory and oxidative stress parameters and to evaluate whether changes in these parameters induced by inhibition of angiotensin converting enzyme (ACE) can affect serum hepcidin level.

Material and Methods: Forty adult male albino rats divided into: Group I $(\mathrm{n}=8)$ : Control group: Rats received subcutaneous injection with the vehicle $(0.3 \mathrm{M} \mathrm{NaHCO} 3,5 \mathrm{ml} / \mathrm{Kg})$ once weekly for 5 weeks. Group II ( $\mathrm{n}=16)$ : Chronic renal failureinduced group (CRF): Rats received subcutaneous injection with folic acid $(300 \mathrm{mg} / \mathrm{kg}$ in $5 \mathrm{ml}$ ) once weekly (dissolved in $0.3 \mathrm{M} \mathrm{NaHCO} 3)$ for 5 weeks. Group III $(n=16)$ : $(\mathrm{CRF}+$ captopril): Chronic renal failure was induced by folic acid as in group II with concomitant administration of the ACE inhibitor; captopril in a daily dose of $(100 \mathrm{mg} / \mathrm{kg} /$ day $)$ orally by gastric gavage. The following was measured in all groups: Blood pressure, Kidney function, haematological and haemostatic parameters, HOMA-IR, lipid profile, CRP, IL6, MDA, SOD and histopathological examination was made.

Results: There was a significant increase in serum hepcidin level in group II compared to control which was correlated positively with serum creatinine, blood urea and negatively with creatinine clearance, while its level decreased significantly in group III compared to group II. A significant increase in bleeding time, WBCT, PT, APTT, INR, FDPs, D dimer and protein $\mathrm{C}$ was found in group II compared to control with an increase in HOMA-IR, CRP, IL6, MDA, systolic and diastolic blood pressure and a significant decrease in $\mathrm{Hb}, \mathrm{MCV}, \mathrm{MCH}$, platelet count, MPV and SOD. In group III, bleeding time, WBCT and protein $\mathrm{C}$ remained significantly elevated versus

Correspondence to: Dr. Maha Abd El-Hamid, E-Mail: y maha m@hotmail.com control and further increase in APTT was found versus group II. A significant decrease in FDPs and D dimer was found in group III versus group II with a significant decrease in HOMAIR, TG, LDL, VLDL, CRP, IL6, MDA, systolic and diastolic BP.

Conclusion: Chronic renal failure induced significant increase in hepcidin level associated with an abnormal coagulation profile. Hepcidin can indirectly affect coagulation profile through its effect on anaemia, IR, oxidative stress and inflammatory mediators. Inhibition of ACE by captopril caused significant improvement of renal function with significant decrease in hepcidin level and significant decrease in hypercoagulopathy.

Key Words: Chronic kidney disease - hepcidin-Coagulation profile-HOMA-IR.

\section{Introduction}

HEPCIDIN is a peptide primary produced by hepatocytes encoded by a gene located on chromosome No 19 [1]. Hepcidin plays a vital role in iron metabolism as it binds to ferroportin which is a protein exists in the cell membrane of Hepatocytes, macrophages, enterocytes, and placental syncytiotrophoblasts, inhibiting release of iron from these cells and so decreasing its availability for erythropoiesis $[2,3,4]$. Its synthesis is inhibited by iron deficiency and hypoxia while iron over load, infection and chronic inflammation increase its level $[5,6]$. Hepcidin level was reported to increase in chronic renal Failure (CRF) patients in many studies and this increase was greater in advanced stages of renal failure and in dialysis patients $[\mathbf{5 , 7 , 8 , 9 ]}$.

Chronic renal failure (CRF) or chronic kidney disease $(\mathrm{CKD})$ is an irreversible slowly progressive deterioration of renal function with high morbidity and mortality rate [10]. Anaemia is a common complication in CKD patients [11]. Although erythropoietin deficiency is the main cause of anaemia 
in these patients, using erythropoiesis stimulating agent (ESA) in treatment of anaemia in CKD patients was associated with resistance and hyporesponsiveness $[\mathbf{1 2 , 1 3 ]}$ suggesting that, other factors participate in this chronic resistant anaemia including hepcidin $[\mathbf{1 4 , 1 5 ]}$.

Abnormal coagulation profile is usually seen in CKD patients resulting in haemostatic disorders including both thromboembolism and bleeding tendency $[16,17]$. Anaemia was reported to have a direct influence on bleeding disorders in uremic patients [18] and delays the initiation of coagulation cascade which was reversed by correction of anaemia [19]. Coagulation profile is also affected by infection, inflammation, insulin resistance, oxidative stress and hypertension [20-22]. An association between hepcidin and all the previous risk factors was reported in a wide variety of diseases including renal patients especially in advanced cases and haemodialysis [23-26].

Renin angiotensin system (RAS) was involved in the pathophysiology of chronic renal failure and its complications including proteinuria, hypertension and pro-thrombotic manifestations $[27,28]$, while its inhibition for example by using angiotensin converting enzyme (ACE) inhibitors has reno-protective, antihypertensive and antithrombotic effect [29,30]. Moreover, angiotensin II was reported to up regulate hepcidin mRNA expression [31]. The previous reports led to the speculation whether hepcidin is linked to the changes in coagulation profile seen in chronic renal failure and if inhibiting RAS by using ACE inhibitors has an influence on serum hepcidin in these cases.

So, the aim of this work was to evaluate changes in coagulation profile in a rat model of chronic renal failure and the possible association of these changes with serum hepcidin in relation to some parameters of renal function, insulin resistance, lipid profile, inflammation and oxidative stress and to evaluate whether changes in these parameters induced by inhibition of angiotensin converting enzyme (ACE) have an impact on serum hepcidin level.

\section{Material and Methods}

\section{1- Animals:}

From March to August 2018, the present study was conducted on 40 adult male albino rats (180$210 \mathrm{~g}$ ) were obtained from animal house Faculty of Veterinary Medicine, Zagazig University. The animals were bred in animal house, Faculty of Medicine, Zagazig University and kept in steel wire cages measured $70 \mathrm{~cm} \times 50 \mathrm{~cm} \times 30 \mathrm{~cm}(4-5 /$ cage). The rats had free access to water and standard chow diet, kept at room temperature on natural light/dark cycle. The rats were left for 1 week to accommodate for laboratory conditions. The experimental protocol was approved by local medical ethics committee, Faculty of Medicine of Zagazig University (Institutional Review Board, IRB). Rats were randomly divided into the following groups: Group I ( $\mathrm{n}=8)$ : Control group: Rats in this group received subcutaneous injection with the vehicle $(0.3 \mathrm{M} \mathrm{NaHCO} 3,5 \mathrm{ml} / \mathrm{Kg})$ once weekly for 5 weeks. Group II $(n=16)$ : Chronic renal failure-induced group (CRF): Rats received subcutaneous injection with folic acid $(300 \mathrm{mg} / \mathrm{kg}$ in $5 \mathrm{ml})$ once weekly (dissolved in 0.3M NaHCO3) for 5 weeks [32]. (5 rats died and 11 rats continued the experiment). Group III $(n=16)$ : Chronic renal failure+captopril group (CRF+Captopril): Chronic renal failure was induced by folic acid as in group II and at the same time they received captopril in a dose of $(100 \mathrm{mg} /$ $\mathrm{kg}$ /day) in tap water given orally by gastric gavage [30] from day one till the end of the experiment (daily for 5 weeks). (2 rats died and 14 rats continued the experiment).

\section{2- Methods:}

Measurement of Blood Pressure: After an overnight fasting, urethane $(1200 \mathrm{mg} / \mathrm{kg})$ was used to anesthetize the rat [33]. After shaving the skin on the ventral side of the neck, small incision was made in the rat neck for tracheostomy and cannulation of carotid artery [34]. For cannulation of carotid artery, a cannula pre-filled with heparinized normal saline $(0.5 \mathrm{IU} / \mathrm{ml})$ was used. A three-way stopcock connected to a pressure transducer was connected to the other end of the cannula. After calibration using a sphygmomanometer, the animal was connected to the Power Lab for BP recording. The procedure was left for 10-20min to stabilize during which the rat was continuously monitored for any bleeding [34].

Sampling of blood: After measuring blood pressure, blood samples were withdrawn from the cannula and were divided as follow:

- $2 \mathrm{ml}$ were collected in special plastic tubes contains $3.2 \%$ sodium citrate solution $(0.1 \mathrm{ml} / 0.9 \mathrm{ml}$ blood $)$ then blood was centrifuged for $10 \mathrm{~min}$ at 1258 r.p.m and plasma was separated to measure prothrombin time (PT), activated partial thromboplastin time (APTT), fibrinogen, fibrinogen degradation products (FDPs), D-dimer, protein C and protein $\mathrm{S}$ activity.

- $1 \mathrm{ml}$ was placed in a test tube to access whole blood clotting time (WBCT). 
- $1 \mathrm{ml}$ was placed in plastic tubes containing EDTA as an anticoagulant and taken fresh to measure different hematological parameters (complete blood picture) including hemoglobin concentration $(\mathrm{Hb})$, mean corpuscular volume (MCV), mean corpuscular hemoglobin $(\mathrm{MCH})$, platelet count and mean platelet volume (MPV).

- The remaining blood was allowed to clot at room temperature and then centrifuged at 3000rpm for $15 \mathrm{~min}$ and serum was stored at $-20^{\circ} \mathrm{C}$ till biochemical assay for measuring hepcidin, iron profile, glucose, insulin, lipid profile, CRP, IL6, MDA and SOD.

Urine collection: $24 \mathrm{~h}$ urine samples were collected from rats placed in metabolic cages and used to determine proteinuria and creatinine urinary concentration.

Creatinine clearance: Was measured as an indicator for glomerular filtration rate (GFR) using the formula [UCr $\times \mathrm{V}$ ]/SCr [35]: $\mathrm{UCr}=$ urinary creatinine concentration; $\mathrm{V}=$ volume of urine per minute; $\mathrm{SCr}=$ serum creatinine concentration.

\section{Biochemical analysis:}

Serum hepcidin using rat (Hepc) ELISA kits (Catalog Number: 201-11-0598, Shanghai sunred biological technology, China) according to Abbasi et al., [36] . Serum iron (SI) using colorimetric method [37], Serum ferritin (SF) was determined photometrically [37], Total iron binding capacity (TIBC) [37] and Transferrin saturation (TS): Transferrin saturation (TS) was calculated from the following equation:

$$
\mathrm{TS}(\%)=\frac{\mathrm{SI}}{\mathrm{TIBC}} \times 100[37]
$$

Hemoglobin content $(\mathrm{Hb})$, mean corpuscular volume (MCV), mean corpuscular hemoglobin $(\mathrm{MCH})$, platelet count and mean platelet volume (MPV): These measurements were done using an automated blood analyzer (Diatron Abacus 380). Serum creatinine ( $\mathrm{SCr}$ ) and blood urea were measured colorimetrically using (Spinreact, S.A.U. ctra. Santa Coloma, 7e-17176 Santest eve de bas (gi), Spain) according to Murray et al., [38] and Kaplan [39] respectively. Creatinine in urine (UCr): like serum creatinine according to Murray et al., [38] Creatinine clearance using the formula [ $\mathrm{UCr}$ $\mathrm{xV}$ /SCr according to Perrone et al., [35] . Protein in urine: According to the manufacturer's protocol by turbidimetry using Microlab 300: Vital Scientific, Germany. Serum IL-6: Was measured by rat IL-6 ELISA kits according to assay instructions (Sigma-Aldrich Company Ltd, Egypt) [40]. C reac- tive proteins (CRP) levels according to Ridker et al., [41] using CRP Kits (Monobind Inc Lake Forest, Ca 92630, USA). Serum glucose level: Glucose enzymatic (GOD-PAP)-liquizyme Kits (Biotechnology, Egypt) was used as stated by Tietz, [42] Serum insulin level: Rat ELISA kit (Product Number: RAB0904, Sigma-Aldrich Chemie GmbH, U.S.A) was used according to Temple et al., [43] Homeostasis model assessment of insulin resistance (HOMA-IR) by using the formula; [HOMA-IR= insulin $(\mathrm{gIU} / \mathrm{mL}) \times$ glucose $(\mathrm{mg} / \mathrm{dL}) / 405]$ [44,45] Serum total cholesterol level by using rat cholesterol ELISA kit (Catalog Number: 2011-11-0198, Shanghai sunred biological technology, China) [42]. Serum triglycerides level: Rat triglycerides ELISA kit: (Catalog Number: 2011-11-0250, Shanghai sunred biological technology, China) was used according to Naito, [46] . Serum high density lipoprotein cholesterol level (HDL): Rat HDL-cholesterol ELISA kit (Catalog Number: 2011-11-0255, Shanghai sunred biological technology, China) was used according to Nauk et al., [47]. Serum low density lipoprotein cholesterol (LDL) level: LDL was recorded using the following formula: $\mathrm{LDL}=\mathrm{TC}-\mathrm{HDL}-\mathrm{TG} / 5$ [48] . Serum very low density lipoproteins (VLDL) levels: according to Tietz, [42] VLDL was calculated as follows: VLDL=TG/5 [42]. Serum superoxide dismutase (SOD): Using superoxide dismutase (SOD) assay kits (Sigma-Aldrich Company Ltd, Egypt. Cat: 19160). Serum malondialdehyde (MDA): Using lipid perioxidation (MDA) assay kits (SigmaAldrich Company Ltd, Egypt. Cat: MAK085). Haemostatic parameters: Bleeding time (BT) as described by Martin, [49]; Whole blood clotting time (WBCT) as described by Quick, [50] ; Prothrombin time (PT) according to Arkin, [51]; Activated partial thromboplastin time (APTT) according to Ansell, [52] ; Plasma fibrinogen levels according to Cooper and Douglas, [53]; fibrinogen degradation products FDPs and Plasma D-dimer levels by ELISA kit, (GenWay Biotech, Inc, ca 40-88234402, USA) according to Declerck et al., [54] Protein $\mathrm{C}$ activity using chromogenic assay and Protein $\mathrm{S}$ by commercially available ELISA kits according to [55].

Histopathological examination: Kidneys were harvested and bisected longitudinally into 3 equal sized slices then fixed in $10 \%$ formalin solution. After automated dehydration kidney slices were embedded in paraffin, sectioned by microtome at 5um and stained with hematoxylin-eosin (HE) stain for blind histopathological examination.

Histopathological scoring: Renal tissue slides were examined for the presence of glomerular and 
tubular sclerosis, inflammatory infiltrate and interstitial fibrosis, as well as the formation of casts and luminal debris and extent of the lesion was scored at 0-3 as follow: 0: minimal or no lesions; 1: $<25 \%$ involved; $2: 25 \%-50 \%$ involved; $3:>50 \%$ involved [56]

\section{Statistical Analysis:}

The data were expressed as mean $\pm \mathrm{SD}$. For quantitative variables, one way ANOVA followed by post hoc test with LSD was done to compare means. The correlations between parameters were assayed by Pearson's correlation coefficient. $p$ values $<0.05$ were considered significant. The statistical analysis was done by using SPSS program (version 18 for windows) (SPSS Inc. Chicago, IL, USA).

\section{Results}

Significant increase in serum hepcidin level was found in group II compared to control $(p<0.001)$. In group III hepcidin level significantly decreased compared to group II levels $(p<0.001)$. kidney function tests including serum creatinine, blood urea and proteinuria showed significant increase and creatinine clearance showed significant decrease in group II relative to control $(p<0.001)$, while in group III, serum creatinine, blood urea and proteinuria decreased significantly and creatinine clearance increased significantly compared to group II $(p<0.001)$ (Table 1).

Iron profile parameters including serum iron, serum ferritin, total iron binding capacity (TIBC) and transferrin saturation (TS), decreased significantly in group II compared to control $(p<0.001$, $p<0.001, p<0.001$ and $p<0.05$ respectively). In group III, no significant difference was found in these levels relative to group II $(p>0.05)$ (Table 1).

Hematological parameters including blood $\mathrm{Hb}$, MCV and MCH showed significant decreased in group II and III compared to control $(p<0.01$, $p<0.001$ and $p<0.001$ respectively). Platelet count and mean platelet volume (MPV) decreased significantly in group II relative to control $(p<0.01)$. In group III, platelet count showed significant decrease relative to both control and group II $(p<0.001)$, while MPV decreased significantly relative to control $(p<0.01)$ but no significant difference was found relative to group II $(p>0.05)$ (Table 1).

Significant increase was found in bleeding time, WBCT, PT, APTT and INR in group II $(p<0.001$, $p<0.05, p<0.01, p<0.001$ and $p<0.001$ respectively) and in group III, bleeding time, WBCT, PT, APTT increased significantly $(p<0.001, p<0.05$, and $p<0.05$ and $p<0.001$ respectively), while INR did not differ significantly compared to control. In group III, relative to group II, no significant difference was found in bleeding time and WBCT $(p>0.05)$, while a significant decrease was found in PT and INR ( $p<0.05$ and $p<0.01$ respectively) and a significant increase in APTT $(p<0.001)$ (Table $1)$.

No significant change was found in plasma fibrinogen level between groups $(p>0.05)$. A significant increase in fibrinogen degradation products (FDPs) ad D dimer was found in group II compared to control ( $p<0.01$ and $p<0.001$ respectively). In group III, a significant decrease was found in FDPs and $\mathrm{D}$ dimer compared to group II $(p<0.01$ and $p<0.001$ respectively), while the difference was insignificant compared to control $(p>0.05)$. A significant increase in protein $\mathrm{C}$ was found in group II and III compared to control $(p<0.05)$ but no significant difference was found in protein $\mathrm{S}$ among groups $(p>0.05)$ (Table 1).

Glucose level and HOMA-IR showed significant increase in group II compared to control $(p<0.001)$. In group III a significant decrease in glucose level and HOMA-IR was found compared to group II ( $p<0.001$ and $p<0.01$ respectively) but still significantly higher than control $(p<0.001$ and $p<0.05$ respectively). No significant difference in insulin level was found between groups $(p>0.05)$ (Table 2).

No significant change was found in lipid profile parameters (TC, TG, HDL, LDL and VLDL) in group II relative to control $(p>0.05)$. In group III, a significant decrease was found in TG, LDL and VLDL relative to control and group II $(p<0.001)$, while TC and HDL revealed non-significant difference relative to control and group II $(p>0.05)$ (Table 2).

Significant increase in CRP and IL6 in group II compared to control $(p<0.001)$, these levels decreased significantly in group III compared to group II $(p<0.001)$ but still significantly higher than control ( $p<0.05$ and $p<0.01$ respectively) (Table 2).

Concerning oxidative stress markers, MDA showed significant increase in group II and SOD significantly decreased relative to control ( $p<$ 0.001 ). In group III, a significant decrease in MDA and a significant increase in SOD was found relative to group II $(p<0.001)$ but these levels were significantly higher than control $(p<0.001)$ (Table 2$)$. 
Table (1): Kidney function, Iron profile and haematological parameters in all studied groups.

\begin{tabular}{|c|c|c|c|}
\hline $\begin{array}{l}\text { Groups } \\
\text { Parameters }\end{array}$ & Group I & Group II & Group III \\
\hline Serum hepcidin (ng/ml) & $382.39 \pm 14.6$ & $1215.7 \pm 23^{* * * *} \mathrm{a}$ & $375.45 \pm 10.7^{* * * *} \mathbf{b}$ \\
\hline Serum creatinine $(\mathrm{mg} / \mathrm{dl})$ & $0.9 \pm 0.04$ & $\begin{array}{l}3.2 \pm 0.1^{* * * a} \mathbf{a} \\
r=0.716^{*}\end{array}$ & $\begin{array}{l}0.8 \pm 0.08^{* * *} \mathbf{b} \\
r=0.384\end{array}$ \\
\hline Blood urea (mg/dl) & $43 \pm 5.5$ & $\begin{array}{l}185 \pm 7.8^{* * *} \mathbf{a} \\
r=0.693 *\end{array}$ & $\begin{array}{l}44 \pm 3.5^{* * * *} \mathbf{b} \\
r=0.119\end{array}$ \\
\hline Creatinine clearance $(\mathrm{ml} / \mathrm{min})$ & $0.73 \pm 0.09$ & $\begin{array}{l}0.38 \pm 0.2^{* * * *} \mathbf{a} \\
r=-0.725\end{array}$ & $\begin{array}{l}0.65 \pm 0.08^{* * * *} \mathbf{b} \\
r=0.311\end{array}$ \\
\hline Proteinuria $(\mathrm{mg} / \mathrm{dl}$ & $5.03 \pm 1.1$ & $\begin{array}{l}15.6 \pm 1.4^{* * *} \mathrm{a} \\
r=0.415\end{array}$ & $\begin{array}{l}9.75 \pm 0.9^{* * * *} \mathbf{a}^{\prime} \mathbf{b} \\
r=0.295\end{array}$ \\
\hline Serum iron $(\mathrm{g} / \mathbf{d})$ & $190.25 \pm 14.2$ & $\begin{array}{l}96.15 \pm 8.7^{* * * *} \mathbf{a} \\
r=0.267\end{array}$ & $\begin{array}{l}106.1 \pm 9.5^{* * * *} \mathbf{a} \\
r=0.361\end{array}$ \\
\hline Serum ferritin (ng/ml) & $40.53 \pm 5.4$ & $\begin{array}{l}8.4 \pm 0.9^{* * *} \mathrm{a} \\
r=0.297\end{array}$ & $\begin{array}{l}10.6 \pm 1.8^{* * * *} \mathbf{a} \\
r=0.218\end{array}$ \\
\hline TIBC $(\mathrm{g} / \mathrm{d})$ & $454.58 \pm 32.86$ & $\begin{array}{l}282.55 \pm 23.5^{* * *} \mathrm{a} \\
r=0.175\end{array}$ & $\begin{array}{l}301.5 \pm 27.4^{* * * *} \mathbf{a} \\
r=0.209\end{array}$ \\
\hline TS $(\%)$ & $41.85 \pm 5.3$ & $\begin{array}{l}34.02 \pm 4.7^{*} \mathrm{a} \\
r=0.230\end{array}$ & $\begin{array}{l}35.19 \pm 6.3^{*} \mathrm{a} \\
r=0.217\end{array}$ \\
\hline $\mathrm{Hb}(\mathrm{gm} / \mathrm{ml})$ & $17.23 \pm 0.8$ & $\begin{array}{l}11.2 \pm 0.7^{* *} \mathrm{a} \\
r=-0.341\end{array}$ & $\begin{array}{l}12.6 \pm 0.4^{* *} \mathrm{a} \\
r=-0.156\end{array}$ \\
\hline MCV (fL/cell) & $78.3 \pm 5.4$ & $\begin{array}{l}48.6 \pm 6.5^{* * * *} \mathrm{a} \\
r=-0.421\end{array}$ & $\begin{array}{l}49.3 \pm 3.6^{* * *} \mathrm{a} \\
r=-0.213\end{array}$ \\
\hline $\mathrm{MCH}(\mathrm{pg} / \mathrm{cell})$ & $28.7 \pm 1.5$ & $\begin{array}{l}19.25 \pm 0.89^{* * *} \mathbf{a} \\
r=-0.177\end{array}$ & $\begin{array}{l}18.7 \pm 1.3^{* * * *} \mathrm{a} \\
r=-0.198\end{array}$ \\
\hline Platelet count $\times 10^{3} / \mathrm{ml}$ & $919 \pm 22.7$ & $\begin{array}{l}647 \pm 13.6^{* * * *} \mathbf{a} \\
r=-0.361\end{array}$ & $\begin{array}{l}483 \pm 32.8^{* * * * a^{* * * * *}} \mathbf{b} \\
r=0.254\end{array}$ \\
\hline Mean platelet volume (MPV) fL & $8.55 \pm 0.5$ & $\begin{array}{l}6.65 \pm 0.8^{* *} \mathrm{a} \\
r=0.126\end{array}$ & $\begin{array}{l}6.25 \pm 0.7^{* * *} \text { a } \\
r=0.193\end{array}$ \\
\hline Bleeding time (sec) & $90 \pm 6$ & $\begin{array}{l}124 \pm 9^{* * *} \mathbf{a} \\
r=0.721 *\end{array}$ & $\begin{array}{l}128 \pm 14^{* * *} \mathbf{a} \\
r=0.184^{2}\end{array}$ \\
\hline WBCT (sec) & $121 \pm 8$ & $\begin{array}{l}146 \pm 5^{*} \mathbf{a} \\
r=0.492\end{array}$ & $\begin{array}{l}143 \pm 11^{*} \mathbf{a} \\
r=0.365\end{array}$ \\
\hline $\mathrm{PT}(\mathrm{sec})$ & $15.2 \pm 1.6$ & $\begin{array}{l}23.6 \pm 5.2^{* *} \mathrm{a} \\
r=0.863^{* *}\end{array}$ & $\begin{array}{l}17.6 \pm 2.3^{*} \mathbf{a} \cdot \mathbf{b} \\
r=0.265\end{array}$ \\
\hline APTT (sec) & $23.57 \pm 1.8$ & $\begin{array}{l}73.2 \pm 3.6^{* * * *} \text { a } \\
r=0.814^{* *}\end{array}$ & $\begin{array}{l}90.6 \pm 8.4^{* * *} \mathbf{a}^{\prime} \mathbf{b} \\
r=0.354\end{array}$ \\
\hline INR & $1.1 \pm 0.05$ & $\begin{array}{l}2.21 \pm 0.08^{* * * * a} \\
r=0.744\end{array}$ & $\begin{array}{l}1.55 \pm 0.07^{* * \mathbf{b}} \\
r=0.275\end{array}$ \\
\hline Fibrinogen (mgldl) & $223 \pm 20.8$ & $\begin{array}{l}225 \pm 15.3 \\
r=0.281\end{array}$ & $\begin{array}{l}220 \pm 17.6 \\
r=0.117\end{array}$ \\
\hline FDPs ( $\mathrm{g} / \mathbf{m l})$ & $2.35 \pm 0.45$ & $\begin{array}{l}3.67 \pm 0.2_{*}^{* *} \mathrm{a} \\
r=0.692\end{array}$ & $\begin{array}{l}2.1 \pm 0.3^{* * *} \mathbf{b} \\
r=-0.261\end{array}$ \\
\hline D dimer ( $\mathrm{g} / \mathbf{m l})$ & $0.089 \pm 0.02$ & $\begin{array}{l}0.22 \pm 0.03^{* * *} \mathrm{a} \\
r=0.722\end{array}$ & $\begin{array}{l}0.1 \pm 0.032^{* * * \mathbf{b}} \\
r=0.245\end{array}$ \\
\hline Protein c (\%) & $56.8 \pm 4.3$ & $\begin{array}{l}77.5 \pm 3 * a \\
r=0.313\end{array}$ & $\begin{array}{l}75.3 \pm 5.2^{*} \mathrm{a} \\
r=0.157\end{array}$ \\
\hline Protein S (\%) & $63.5 \pm 2.7$ & $\begin{array}{l}65 \pm 2.5 \\
r=0.288\end{array}$ & $\begin{array}{l}67.7 \pm 3.2 \\
r=0.197\end{array}$ \\
\hline
\end{tabular}

$*=$ Significant $(p<0.05) . \quad * *=$ Significant $(p<0.01) . \quad * * *=$ Significant $(p<0.001) . \quad$ a: Versus (I). $\quad$ b : Versus (II). 
Significant increase in systolic and diastolic blood pressure was found in group II compared to control ( $p<0.01$ and $p<0.001$ respectively), while a significant decrease in both was found in group III compared to group II ( $p<0.05$ and $p<0.001$ respectively) but no significant difference was found in group III compared to control $(p>0.05)$ (Table 2, Figs. 4,5,6).

Serum hepcidin level was positively correlated with serum creatinine, blood urea and negatively correlated with creatinine clearance $(r=0.716$, $p<0.05 ; r=0.693, p<0.05$ and $r=-0.725, p<0.05$ respectively) in group II but not in other groups $(p>0.05)$ (Table 1).

A significant positive correlation was found between serum hepcidin and bleeding time, PT,
APTT and INR $(r=0.721, p<0.05 ; r=0.863, p<0.01$; $r=0.814, p<0.01 ; r=0.744, p<0.05$ respectively) in group II but not in other groups. Also FDPs and $\mathrm{D}$ dimer correlated positively with hepcidin in group II only ( $r=0.692, p<0.05$ and $r=0.722, p<0.05$ respectively) (Table 1$)$.

Group II also showed a significant positive correlation between serum hepcidin and blood glucose, HOMA-IR ( $r=0.724, p<0.05$ and $r=0$. $794, p<0.01$ respectively) and with the inflammatory mediators; CRP and IL6 ( $r=0.814, p<0.01$ and $r=0.781, p<0.01$ respectively). As regard oxidative stress markers, serum hepcidin correlated positively with MDA $(r=0.801, p<0.01)$ and negatively with SOD in group II $(r=0.731, p<0.05)$ (Table 2).

Table (2): Serum level of measured metabolic, inflammatory and oxidative stress parameters in all studied groups.

\begin{tabular}{|c|c|c|c|}
\hline $\begin{array}{l}\text { Groups } \\
\text { Parameters }\end{array}$ & Group I & Group II & Group III \\
\hline Glucose (mg/dl) & $115.8 \pm 7.1$ & $\begin{array}{l}179.3 \pm 5.5^{* * * *} \mathrm{a} \\
r=0.724^{2}\end{array}$ & $\begin{array}{l}141.6 \pm 8.5^{* * *} \mathbf{a} \cdot \mathbf{b} \\
r=0.184\end{array}$ \\
\hline Insulin ( لUاml) & $12.5 \pm 2.6$ & $\begin{array}{l}15.1 \pm 1.8 \\
r=0.255\end{array}$ & $\begin{array}{l}13.6 \pm 1.5 \\
r=0.314\end{array}$ \\
\hline HOMA-IR & $3.57 \pm 0.2$ & $\begin{array}{l}6.99 \pm 0.4^{* * * * a} \mathbf{a} \\
r=0.794^{* *}\end{array}$ & $\begin{array}{l}4.75 \pm 0.5^{*} \mathbf{a}^{, * *} \mathbf{b} \\
r=0.322\end{array}$ \\
\hline $\mathrm{TC}(\mathrm{mg} / \mathrm{dl})$ & $72.8 \pm 5.7$ & $\begin{array}{l}70.5 \pm 11 \\
r=0.219\end{array}$ & $\begin{array}{l}67 \pm 9.1 \\
r=0.157\end{array}$ \\
\hline $\mathrm{TG}(\mathrm{mg} / \mathrm{dl})$ & $44.5 \pm 6.5$ & $\begin{array}{l}41.05 \pm 3.3 \\
r=0.378\end{array}$ & $\begin{array}{l}27.4 \pm 7.6^{* * * *} \mathbf{a} \cdot \mathbf{b} \\
r=0.190\end{array}$ \\
\hline HDL (mg/dl) & $42.3 \pm 33.1$ & $\begin{array}{l}42.5 \pm 3.6 \\
r=-0.283\end{array}$ & $\begin{array}{l}50.5 \pm 5.8 \\
r=-0.494\end{array}$ \\
\hline LDL (mg/dl) & $21.47 \pm 7.1$ & $\begin{array}{l}19.79 \pm 7.5 \\
r=-0.241\end{array}$ & $\begin{array}{l}11.6 \pm 8.6^{* * *} \mathbf{a}, \mathbf{b} \\
r=-0.327\end{array}$ \\
\hline VLDL (mg/dl) & $8.9 \pm 1.8$ & $\begin{array}{l}8.21 \pm 3.4 \\
r=-0.296\end{array}$ & $\begin{array}{l}5.48 \pm 0.7^{* * * *} \mathbf{a}^{\prime} \mathbf{b} \\
r=-0.159\end{array}$ \\
\hline $\mathrm{CRP}(\mathrm{mg} / \mathrm{ml})$ & $0.52 \pm 0.02$ & $\begin{array}{l}1.9 \pm 0.12^{* * *} \mathbf{a} \\
r=0.814^{* *}\end{array}$ & $\begin{array}{l}0.79 \pm 0.06^{*} \mathbf{a}^{, * * * *} \mathbf{b} \\
r=0.342\end{array}$ \\
\hline IL6 (pg/ml) & $119.4 \pm 6.3$ & $\begin{array}{l}255.3 \pm 17.4^{* * * *} \mathrm{a} \\
r=0.781^{* * *}\end{array}$ & $\begin{array}{l}164 \pm .15 .2^{* *} \mathbf{a}^{, * * * *} \mathbf{b} \\
r=0.423\end{array}$ \\
\hline $\operatorname{MDA}(\mathrm{nmol} / \mathrm{ml})$ & $8.5 \pm 0.4$ & $\begin{array}{l}19.85 \pm 1.5^{* * *} \mathbf{a} \\
r=0.801\end{array}$ & $\begin{array}{l}11.4 \pm 1.7^{* * *} \mathbf{a , b} \\
r=0.462\end{array}$ \\
\hline $\mathrm{SOD}(\mathrm{IU} / \mathrm{ml})$ & $336.7 \pm 12.6$ & $\begin{array}{l}217.5 \pm 15.3^{* * *} \mathrm{a} \\
r=-0.731^{*}\end{array}$ & $\begin{array}{l}285.6 \pm 9.6^{* * *} \mathbf{a} \cdot \mathbf{b} \\
r=-0.411\end{array}$ \\
\hline Systolic BP (mmHg) & $86.5 \pm 2$ & $\begin{array}{l}121 \pm 11^{* *} \mathrm{a} \\
r=0.325\end{array}$ & $\begin{array}{l}96 \pm 5 * \mathbf{b} \\
r=0.410\end{array}$ \\
\hline Diastolic BP (mmHg) & $65 \pm 2$ & $\begin{array}{l}110.5 \pm 7^{* * *} \mathrm{a} \\
r=0.216\end{array}$ & $\begin{array}{l}72 \pm 3^{* * *} \mathbf{b} \\
r=0.179\end{array}$ \\
\hline
\end{tabular}

$*=$ Significant $(p<0.05) . \quad * *=$ Significant $(p<0.01) . \quad * * *=$ Significant $(p<0.001) . \quad$ a: Versus (I). $\quad$ b: Versus (II). 
Histopathological examination of the kidney revealed normal architecture of renal tissues in control group (Fig. 1). Group II showed marked glomerular sclerosis, heavy inflammatory infiltrate, and marked tubular necrosis, dilatation with casts and debris (Fig. 2). In group III, captopril treatment induced considerable improvement of structural and histological appearance of the kidney with mild tubular dilatation and degeneration (Fig. 3). Histopthological scoring revealed significant increase in group II compared to group I $(p<0.001)$ with significant positive correlation with serum hepcidin level $(r=0.814, p<0.01)$, while in group III renal tissue scoring decreased significantly compared to group II $(p<0.001)$ but did not correlate with hepcidin $(p>0.05)$ (Table 3$)$.

Table (3):Renal histopathological score in all studied groups.

\begin{tabular}{lccc}
\hline $\begin{array}{l}\text { Groups } \\
\text { Parameters }\end{array}$ & Group I & Group II & Group III \\
\hline 0 & $\begin{array}{c}2.9 \pm 0.08^{* * * * *} \\
r=0.814^{* *}\end{array}$ & $\begin{array}{c}1.53 \pm 0.7^{* * * * *} \\
r=0.251\end{array}$ \\
& & $\mathbf{a}^{\prime} \mathbf{b}$ \\
\end{tabular}

$*=$ Significant $(p<0.05) . \quad * *=$ Significant $(p<0.01)$.

$* * *=$ Significant $(p<0.001)$. a: Versus (I). b: Versus (II).

Photomicroscopic pictures of kidney tissue stained with Haematoxylin \& Eosin and viewed under high power magnification $\times 400$.

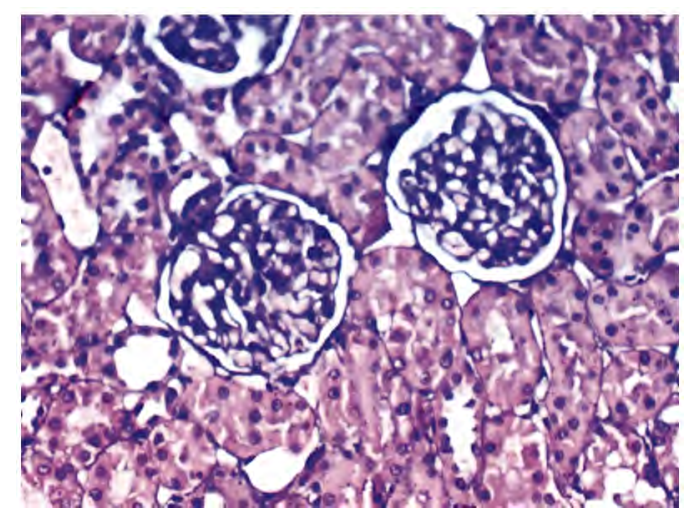

Fig. (1): Control group showing no obvious damage to the glomeruli or tubules in the kidneys.

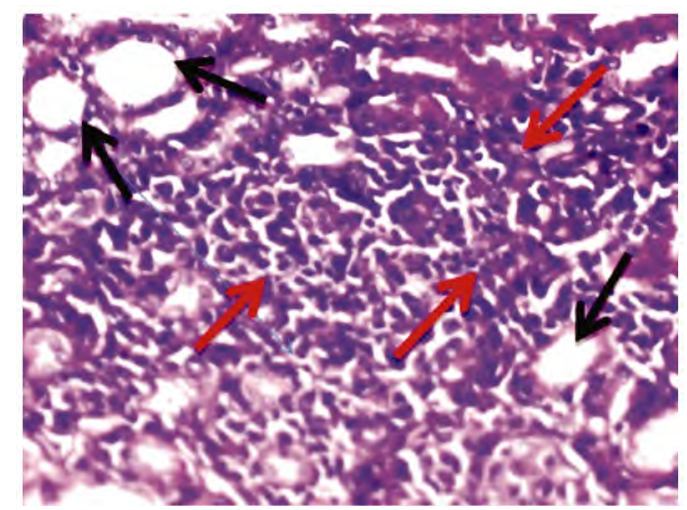

Fig. (2): CRF group showing chronic interstitial nephritis characterized by extensive infiltration with lymphocytes and macrophages (red arrow), microcystic dilatation of tubules (black arrow).

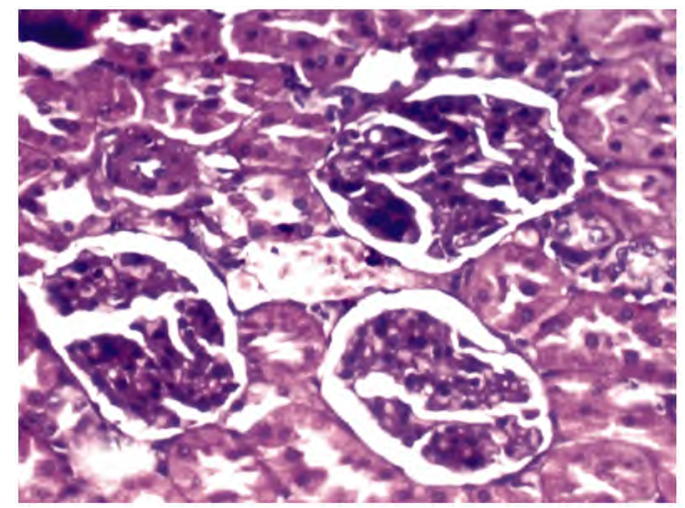

Fig. (3): CRF+captopril group showing considerable improvement in structural and histological appearance of kidney sections).

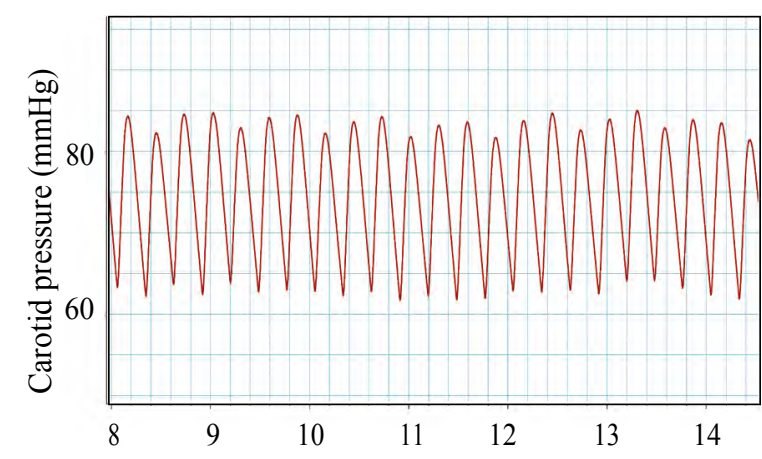

Fig. (4): Blood pressure measured in control group (GI).

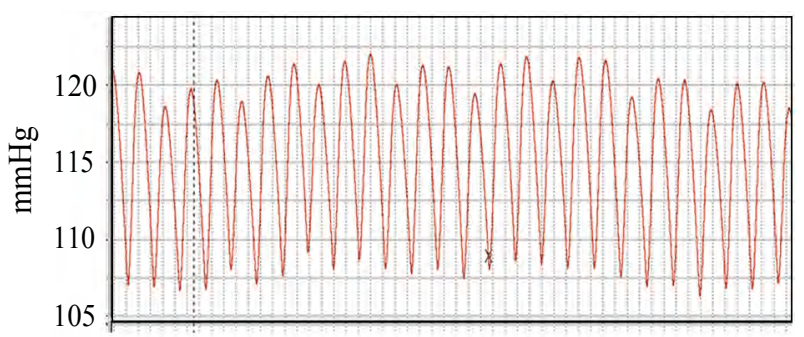

Fig. (5): Blood pressure measured in CRF group (GII).

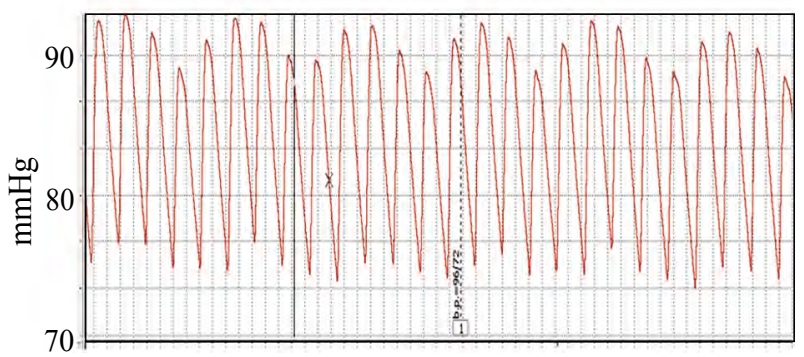

Fig. (6): Blood pressure measured in CRF+captopril group (GIII).

\section{Discussion}

Chronic renal failure in group II was accompanied by significant increase in blood urea, serum creatinine and proteinuria with significant decrease in creatinine clearance indicating impaired renal function. Histopathological examination also revealed significant glomerular sclerosis and inter- 
stitial fibrosis of renal tissue. Approximately 3 fold increase in serum hepcidin was found in this group relative to control with positive correlation with serum creatinine and blood urea and negative correlation with creatinine clearance which is an indicator for glomerular filtration rate (GFR). This is in line with numerous studies that identified an increase in hepcidin level in renal failure with an inverse correlation with GFR and the increase was greater in advanced stages of the disease $[\mathbf{5 , 7 , 8 , 9 ]}$ The kidney is a major site for hepcidin excretion [57], so its level increases in impaired renal function. Accumulation of toxic metabolites normally excreted by the kidney and chronic inflammatory state seen in renal failure can increase hepatic hepcidin synthesis $[\mathbf{5 8 , 5 9 ]}$. This was supported in our results by the significant increase in the inflammatory markers, IL6 and C reactive protein (CRP) with positive correlation with hepcidin in CRF group relative to control which can induce an increase in hepcidin level. This was previously reported by Tandara et al., [60] who reported a positive correlation between hepcidin and inflammatory markers including IL6 and CRP. IL-6 induces binding of STAT-3 (signal transducer and activator of transcription) to hepcidin promoter leading to an increase in hepcidin activity $[61,62]$ Moreover lipopoly-saccharide administration in healthy subjects was reported to induce an increase in IL-6 levels followed by an increase in hepcidin levels, and then hypoferremia [63], while using anti-IL-6 receptor antibody suppressed hepcidin synthesis and improved anaemia [64,65].

The results also revealed significant decrease in haemoglobin $(\mathrm{Hb}), \mathrm{MCV}$ and $\mathrm{MCH}$ in $\mathrm{CRF}$ group indicating anaemia. Serum iron, serum ferritin and transferrin saturation significantly decreased indicating absolute iron deficiency anaemia [66] and the very low ferritin level seen in our results $(<12)$ indicates almost absent iron stores according to Thomas et al., [67]. None of the previous parameters correlated with hepcidin. In accordance with our results, Rubab et al., [68] found no association between hepcidin and serum iron, TIBC or ferritin in end stage CKD patients. Opposite to our findings, Goyal et al., [69] and Mercadal et al., [15] found that serum hepcidin correlated positively with Ferritin and transferrin saturation in uremic patients. Absence of significant correlation in our results may be explained by the fact that, iron status is not the only regulator of hepcidin. It was reported to be one of the acute phase reactant that increase in infection and chronic inflammation as the case in chronic renal failure [58,59]. It should be also considered that, the elevated hepcidin levels although not correlated with markers of anaemia in our study but can share in the induction of anaemia by decreasing iron absorption and blocking its release from reticuloendothelial system leading to worsening of the already limited iron availability for erythropoiesis [70]. So, we can indicate that, in our study, anaemia is due to both absolute and functional iron deficiency due to the presence of high hepcidin in association with low-instead of high-ferritin level, while in pure functional iron deficiency high hepcidin is associated with high ferritin level [67].

Coagulation profile in CRF group showed significant prolongation in bleeding time, WBCT, PT, APTT, and INR relative to control. This was associated with a significant increase in protein $\mathrm{C}$ activity and a significant decrease in platelet count and MPV. A significant increase in fibrinogen degradation products (FDPs) and D dimer was also found, while fibrinogen level and protein $\mathrm{S}$ showed no significant difference relative to control. Serum hepcidin correlated positively with bleeding time, PT, APTT and INR in this group.

Profound changes in the coagulation system are found in patients with renal failure, as they are susceptible to episodes of both prolonged bleeding and excessive thrombi formation [71]. In CKD especially in advanced stages there is an increased risk of cutaneous, mucosal, or serosal bleeding which ranges from mild bleeding as ecchymosis and gingival bleeding to life-threatening as spontaneous gastrointestinal bleeding or intracranial haemorrhage [16]. The prolonged bleeding time, WBCT, PT, APTT and INR seen in our results indicates bleeding tendency. The significant increase in protein $\mathrm{C}$ activity found in our study can be a cause of this disturbance as protein $\mathrm{C}$ is a potent natural anticoagulant and its activity was reported by some authors to increase in chronic renal failure [72], others found a decrease [73] or no significant change in protein $\mathrm{C}$ and protein $\mathrm{S}$ in uremic patients [74].

The cause of this bleeding tendency was also reported to be attributed to a defect either in platelet count or function. In our results, platelet count and mean platelet volume (MPV) were significantly lower than control. MPV was reported to affect platelet function with hyperactivity when increase and impaired function when decrease [75]. Platelet dysfunction in CKD was also reported to be attributed to abnormal function of platelet glycoproteins as GPIIb and GPIIIa, defect in the release of serotonin and ADP from platelet granules and dysregulated metabolism of arachidonic acid and prostaglandin leading to impairment of platelet adhesion 
and aggregation or may also be a result of accumulation of uremic toxins including guanidinosuccinic acid and methyl guanidine [16]

We also found a significant increase in FDPs and $\mathrm{D}$ dimer with significant positive correlation with hepcidin in CRF group relative to control. Such result indicates thromboembolic manifestations in this group. In accordance, elevated hepcidin levels were reported to be an independent risk factor for atherosclerosis and ischemic disease in different populations including uremic patients [26]. Thromboembolic manifestation and hypercoagulopathy are commonly described in CKD patients as chronic kidney disease is usually referred to as a pro-coagulant state even in early stages [76,77]. Reduced tissue plasminogen activator [78] and increase of $\mathrm{D}$ dimer (which is in line with our results), increase in plasminogen activator inhibitor1 [79,80], tissue factor [81], von Will brand factor [82], factor XIIa and VIIa [83] were all reported to be possible causes of this coagulopathy in CKD. Fibrinogen level was also reported to increase in $\mathrm{CKD}$, increasing blood viscosity and predispose to thrombosis [84]; however in our study no significant change was found in fibrinogen level in CKD group relative to control.

In chronic kidney disease, complex abnormalities in cellular metabolism with reduced antioxidant and increased pro-oxidant activity are present leading to enhanced oxidative stress which plays a key role in the development of clinical complications in CKD including atherosclerosis and thrombotic manifestations [85]. In CRF group, oxidative stress markers revealed significant increase in MDA and significant decrease in SOD and these changes were correlated with the elevated hepcidin (positively with MDA and negatively with SOD). An association between elevated hepcidin levels and increased oxidative stress was previously reported $[\mathbf{2 5 , 8 6 ]}$. In support with these findings, hepcidin overexpression was reported to increase the generation of reactive oxygen species (ROS), while suppression of hepcidin reversed these changes [87] indicating a role for hepcidin in the increased oxidative stress and hence coagulopathy seen in CKD.

Metabolic parameters are affected in CKD and may also play a role in the observed changes in coagulation profile. Insulin resistance (IR) was observed in CKD patients in early and in different stages of the disease even in absence of clinical diabetes [88] and it was associated with coagulation disturbance, thrombotic manifestations and atherosclerosis [89]. In our results, we demonstrated a significant increase in blood glucose level and HOMA-IR and both correlated positively with serum hepcidin in CRF group. Hepcidin level was previously found to be associated with IR and an increase in hepcidin level and gene expression was reported in diabetic patients and metabolic syndrome with or without diabetes $[\mathbf{9 0 , 9 1 ]}$.

Inflammatory mediators have great influence on IR. TNF-a was referred to as the main causative factor in the development of IR [92], while IL-6 inhibits the metabolism of non-oxidative glucose and decreases lipoprotein lipase leading to increases in plasma triglycerides level [93]. Hepcidin was reported to have an anti-inflammatory effect as hepcidin was found to suppress the transcription and secretion of IL-6 and TNF- $a$ in cultured macrophages and in vivo mouse models [94], while lack of hepcidin was found to be associated with increased mRNA expression and elevated serum level of IL-6 and TNF- $a$ in iron deficient mice [95]. So, the elevated hepcidin levels seen in CRF group may be an adaptive response of the body in a trial to decrease the inflammatory reactions in CKD and hence limit its deleterious consequences on IR, lipid metabolism and oxidative stress which all affect coagulation profile.

No significant change in lipid profile was observed in CRF group. Similar to our results, Khan and Ola [96] found no significant difference in lipid profile between normal and renal impaired diabetic rats. Opposite to these finding, dyslipidaemia was frequently associated with $\mathrm{CKD}$ and can accelerate the progression of the disease [97]. Species difference or nutritional factors may be a cause of this inconsistency as in our study rats were fed on normal chow diet and the amount of food intake can be impaired with the progression of renal failure throughout the study which can affect lipid profile. In addition, longer duration of the study might be needed for the dyslipidaemic effects of renal failure to appear.

ion of RAS by using angiotensin converting enzyme inhibitor (captopril) and evaluate whether its protective effect on the kidney was associated with changes in hepcidin level.

Our results revealed a significant improvement of renal function in captopril treated group (group III) proved by significant decrease in serum creatinine, blood urea and proteinuria and significant increase in creatinine clearance with improved histo-pathological changes relative to group II. Significant decrease in hepcidin levels was obvious in this group relative to group III and these levels 
became close to control group levels. Matching with our findings, Ishizaka et al., [31] demonstrated that, administration of angiotensin II was able to induce $\sim 4.7$ fold increase in hepcidin mRNA which was associated with significant renal damage, while inhibition of RAS reversed these changes.

A significant decrease in blood sugar and HOMA-IR was detected and a significant decrease in TG, LDL and VLDL was observed in captopril treated group relative to group II. Moreover, a significant decrease in oxidative stress as indicated by significant decrease in MDA and significant increase in SOD was found. Inflammatory marker also decreased significantly including IL6 and CRP. All these factors particularly the reduction in IL6 may play a role in the reduced hepcidin seen in this group. In accordance with these findings, blocking RAS was reported to lower blood glucose, improve insulin resistance [28,102,103], improve lipid profile [104,105], decrease oxidative stress and inflammatory mediators [106,107] .

No significant change in $\mathrm{Hb}, \mathrm{MCV}, \mathrm{MCH}$, serum iron, ferritin, TIBC and TS in group III relative to group II and these levels were significantly lower than control group. In line with our results, the use of angiotensin-converting enzyme (ACE) inhibitors has been associated with suppression of erythropoiesis [108]. When kidney function is normal, the decrease in RBC production is almost not clinically apparent, while in patients with renal insufficiency, ACE inhibitor can induce clinically relevant anaemia [109]. The iron deficiency anaemia together with the decrease in inflammatory and oxidative stress markers can explain the significant reduction of hepcidin level in captopril treated group relative to CRF group as iron deficiency anaemia is a potent inhibitor of hepcidin synthesis. In CRF group (group II), the stimulating effect of iron deficiency anaemia on hepcidin synthesis was not apparent due to the concomitant increase in inflammatory mediators especially IL6 which increases hepcidin level.

Bleeding time and WBCT also remained elevated and no significant difference and even a further increase in APTT was noticed relative to CRF group. Treatment with ACE inhibitors was reported in some case report studies to supress bone marrow function especially in high doses producing pancytopenia including thrombocytopenia [110]. This is in accordance with our study as we found a significant decrease in platelet count relative to control and CRF group and also a significant decrease in MPV relative to control, moreover, our results revealed a significant increase in protein $\mathrm{C}$ which all can account for this bleeding tendency. Besides, anaemia found in this group can affect haemostasis with a delay in initiation of clot formation and decreasing platelet adhesion as was referred to [19,98]. Matching with our study, according to Al Sheibani [111] treatment of rats with captopril for 4 weeks caused significant prolongation of PT and APTT but opposite to our results they found no effect on platelets counts.

Captopril induced significant decrease in FDPs and D dimer in group III relative to group II, indicating a decrease in hper-coagulable state. This comes in line with previous reports indicated that, captopril treatment in myocardial infraction induced significant decrease in the frequency of recurrent thrombosis and these changes were linked to accumulation of bradykinins [112], while administration of angiotensin II was found to enhance thrombosis by increasing plasminogen activator inhibitor type 1 (PAI-1), tissue factor (TF), D dimer and fibrinogen [79]. The decrease in FDPs and D dimer did not correlate with serum hepcidin in this group, probably due to the presence of other factors improved by ACE inhibitors that can contribute to these observed changes in coagulation profile including insulin sensitivity, lipid profile, blood pressure, inflammatory markers and oxidative stress.

Moreover, blood pressure recorded in our study revealed significant increase in systolic and diastolic BP in CRF group which is in line with previous reports about an association between high hepcidin level and hypertension [23]. Over-activation of RAS was found to be involved in the pathogenesis of renal hypertension [28,79]. As expected, using captopril in group III caused normalization of BP to control values. Hypertension can induce endothelial injury and provoke thrombotic manifestation [112]. Correction of hypertension in this group can help to reduce thromboembolic coagulopathy.

\section{Conclusion:}

Chronic renal failure induced significant increase in serum hepcidin level in association with abnormal coagulation profile including both hypercoagulopathy and bleeding tendency. Hepcidin can indirectly affect coagulation profile through its effect on anaemia, IR, oxidative stress and inflammatory mediators. However, establishing a direct relationship between hepcidin and coagulation profile in chronic renal failure needs further studies involving experimental administration of hepcidin peptide. 
Inhibition of ACE using captopril resulted in significant improvement of renal function with significant decrease in hepcidin level and significant decrease in hypercoagulable state that could be induced by its favourable effect on blood pressure, IR, oxidative stress and inflammatory mediators but anaemia and bleeding tendency still present indicating that, in spite of the beneficial effect for ACE inhibitors in CRF but continuous monitoring of coagulation profile should be taken into consideration.

Acknowledgment: to Dr. Hayam Rashed, assistant Professor of Pathology, Faculty of Medicine, Zagazig University for performing the histopathological study.

\section{References}

1- PARK C.H., VALORE E.V., WARNING A.J. and GANZ T.: Hepcidin, a urinary antimicrobial peptide synthesized in the liver. J. Biol. Chem., 276: 7806-10, 2001.

2- RIVERA S., NEMETH E., GABAYAN V., LOPEZ M.A., FARSHIDI D. and GANZ T.: Synthetic hepcidin causes rapid dose-dependent hypoferremia and is concentrated in ferroportin-containing organs. Blood, 106: 2196-9, 2005 .

3- DONOVAN A., LIMA C.A., PINKUS J.L., PINKUS G.S., ZON L.I., ROBINE S., et al.: The iron exporter ferroportin/Slc40a1 is essential for iron homeostasis. Cell. Metab., 1: 191-200, 2005

4- PREZA G.C., PINON R., GANZ T. and NEMETH E.: Cellular catabolism of the iron-regulatory peptide hormone hepcidin. PLoS One., 8: e58934, 2013.

5- TSUCHIYA K. and NITTA K.: Hepcidin is a potential regulator of iron status in chronic kidney disease. Ther. Apher. Dial., 17:1-8, 2013.

6- WAGNER M., ASHBY D.R., KURTZ C., ALAM A., BUSBRIDGE M., RAFF U., et al.: Hepcidin-25 in diabetic chronic kidney disease is predictive for mortality and progression to end stage renal disease. PLoS One., 10: e0123072, 2015.

7- ASHBY D.R., GALE D.P., BUSBRIDGE M., MURPHY K.G., DUNCAN N.D., CAIRNS T.D., et al.: Plasma hepcidin levels are elevated but responsive to erythropoietin therapy in renal disease. Kidney Int., 75: 976-81, 2009.

8- TOMOSUGI N., KAWABATA H., WAKATABE R., HIGUCHI M., YAMAYA H., UMEHARA H., et al.: Detection of serum hepcidin in renal failure and inflammation by using Protein. Chip. System. Blood, 108: 1381-7, 2006.

9- COYNE D.W.: Hepcidin: Clinical utility as a diagnostic tool and therapeutic target. Kidney Int., 80: 240-4, 2011.

10-JHA V., GARCIA-GARCIA G., ISEKI K LI Z., NAICKER S., PLATTNER B., et al.: Chronic kidney disease: Global dimension and perspectives. Lancet, 382: 260-72, 2013.

11- BARGMAN J.M. and SKORECKI K.: Chronic kidney disease. In: Longo D.L., Fauci A.S., Kasper D.L., Hauser S.L., Jameson J.L., Loscalzo J., editors. Harrison's Principles of Internal Medicine. 18 th ed. New York: The McGraw Hill Companies, Inc., 2012.
12- DE FRANCISCO A.L., STENVINKEL P. and VAULONT S.: Inflammation and its impact on anaemia in chronic kidney disease: From haemoglobin variability to hyporesponsiveness. NDT. Plus., 2 (1): i18-26, 2009.

13- RICHARDSON D.: Clinical factors influencing sensitivity and response to epoetin. Nephrol Dial. Transplant., 17 (1): 53-9, 2002.

14- UEHATA T., TOMOSUGI N., SHOJI T., SAKAGUCHI Y., SUZUKI A., KANEKO T., et al.: Serum hepcidin-25 levels and anemia in non-dialysis chronic kidney disease patients: A cross-sectional study. Nephrol. Dial. Transplant., 27: 1076-83, 2012.

15- MERCADAL L., METZGER M., HAYMANN J.P., THERVET E., BOFFA J.J., FLAMANT M., et al.: The relation of hepcidin to iron disorders, inflammation and hemoglobin in chronic kidney disease. PLoS. One., 9: e99781, 2014.

16- JALAL D.I., CHONCHOL M. and TARGHER G.: Disorders of hemostasis associated with chronic kidney disease. Semin. Thromb. Hemost., 36: 34-40, 2010.

17- MOLINO D., DE LUCIA D. and GASPARE DE SANTO N.: Coagulation disorders in uremia. Semin. Nephrol., 26: 46-51, 2006

18- GALBUSERA M., REMUZZI G. and BOCCARDO P. Treatment of bleeding in dialysis patients. Semin. Dial., 22: 279-286, 2009.

19- WILFRIED W.H. ROELOFFZEN, HANNEKE C. KLUINNELEMANS, LOTTE BOSMAN and JOOST T.M.W Effects of red blood cells on hemostasis. Transfusion, 50: 1536-1544, 2010.

20- MEZZANO D., PAIS EO., ARANDA E., et al.: Inflammation, not hyperhomocysteinemia, is related to oxidative stress and hemostatic and endothelial dysfunction in uremia. Kidney Int., 60: 1844-1850, 2001.

21- GLORIEUX G., COHEN G., JANKOWSKI J., et al.: Platelet/leukocyte activation, inflammation, and uremia. Semin Dial., 22: 423-427, 2009.

22- SRIVASTAVA N., SINGH R.G., USHA KUMAR A. and SINGH S.: Insulin Resistance in Predialytic, Nondiabetic, Chronic Kidney Disease Patients: A Hospital-based Study in Eastern Uttar Pradesh, India. Saudi. J. Kidney. Dis. Transpl., 28 (1): 36-43, 2017.

23- SUÁREZ-ORTEGÓN M.F., ARBELÁEZ A., MOSQUERA M., MORENO-NAVARRETE J.M., AGUILARPLATA C. and FERNÁNDEZ-REAL J.M.: Circulating hepcidin is independently associated with systolic blood pressure in apparently healthy individuals. Arch. Med. Res., 46: 507-513, 2015.

24- MARTINELLI N., TRAGLIA M., CAMPOSTRINI N., BIINO G., CORBELLA M., SALA C., et al.: Increased serum hepcidin levels in subjects with the metabolic syndrome: A population study. PLoS. One., 7: e48250., 2012.

25- CHOI S.O., CHO Y.S., KIM H.L. and PARK J.W.: ROS mediate the hypoxic repression of the hepcidin gene by inhibiting C/EBPalpha and STAT-3. Biochem. Biophys Res. Commun., 356: 312-7, 2007.

26- LI H., FENG S.J., SU L.L., WANG W., ZHANG X.D. and WANG S.X.: Serum hepcidin predicts uremic accelerated atherosclerosis in chronic hemodialysis patients 
with diabetic nephropathy. Chin. Med. J. (Engl)., 128: 1351-7, 2015.

27- BERL T.: Renal protection by inhibition of the renin angiotensin aldosterone System. Journal of the ReninAngiotensin-Aldosterone System, 10 (1): 1-8, 2009.

28- WILLIAMS B.: Drug discovery in renin-angiotensin system intervention: Past and future. Ther. Adv. Cardiovasc. Dis., 10 (3): 118-125, 2016.

29- VAN DER MEER M., CRAVEDI P. and REMUZZI G.: Role of renin angiotensin system inhibition in kidney repair. Fibrogenesis \& Tissue Repair., 3:7-18, 2010.

30- HRENÁK J., ARENDÁŠOVÁ K., RAJKOVIC ¿OVÁ R., AZIRIOVÁ S., REPOVÁ K., KRAJCÍROVIC OVÁ K., CELEC P., KAMODYOVÁ N., BÁRTA A., ADAMCOVÁ M., PAULIS L. and SIMKO F.: Protective Effect of Captopril, Olmesartan, Melatonin and Compound 21 on Doxorubicin-Induced Nephrotoxicity in Rats. Physiol. Res., 62 (1): S181-S189, 2013.

31- ISHIZAKA N., SAITO K., FURUTA K., Matsuzaki G., KOIKE K., NOIRI E. and NAGAI R.: Angiotensin IIInduced Regulation of the Expression and Localization of Iron Metabolism-Related Genes in the Rat Kidney. Hypertens Res., 30: 195-202, 2007.

32- NABAE K., DOI Y., TAKAHASHI S., ICHIHARA T., TODA C., UEDA K., OKAMOTO Y. and SHIRAI T.: Toxicity of di (2-ethylhexyl) phthalate and di (2-ethylhexyl) adipate under conditions of renal dysfunction induced with folic acid in rats: Enhancement of male reproductive toxicity of DEHP is associated with an increase of the mono-derivative. Reproductive Toxicology, 22 (3): 411417, 2006.

33- MILLER F.N. and WIEGMAN D.L.: Anesthesia-induced alteration of small vessel response to norepinephrine. Eur. J. Pharmacol., 44 (4): 331-7, 1977.

34- PARASURAMAN S. and RAVEENDRAN R.: Measurement of invasive blood pressure in rats. J. Pharmacol. Pharmacother., 3 (2): 172-77, 2012.

35- PERRONE R.D., MADIAS N.E. and LEVEY A.S.: Serum creatinine as an index of renal function: New insights into old concepts. Clin. Chem., 38: 1933, 1992.

36- ABBASI MH, FATIMA S., NAZ N., MALIK I.A. and SHEIKH N.: Effect of Nerium oleander (NO) Leaves Extract on Serum hepcidin, Total Iron, and Infiltration of ED1 Positive Cells in Albino Rat. Bio. Med. Res. Int., 18, 2013.

37- BURITS C.A. and ASHWOOD E.R.: Methods for the. determination of serum iron, iron binding capacity, and transferrin saturation. Tietz Textbook of Clinical Chemistry, $3^{\text {rd }}$ ed. AACC, Chapter., 46: 1701-1703, 1999.

38- MURRAY R.L.: Nonprotein compounds, In: Kaplan L.A. and Pesce A.J. (editors), Clinical chemistry: Theory, analysis and co-relation, Mosby CV Toranto, 1230-68, 1984.

39- KAPLAN A., UREA KAPLAN A., et al.: Clin Chem the C.V. Mosby Co., St Louis. Toronto. Princeton., 12571260, 437, 418, 1984.

40- SONG X.Y., GU M., JIN W.W., KLINMAN D.M. and WAHL S.M.: Plasmid DNA encoding transforming growth factor-beta 1 suppresses chronic disease in a streptococcal cell wall-induced arthritis model. J. Clin. Invest., 101 (12): 2615-2621, 1998.

41- RIDKER P.M., RIFAI N., PFEFFER M.A., SACKS F M., MOYE L.A., GOLDMAN S., FLAKER G.C. and BRAUNWALD E.: Inflammation, Pravastatin and the risk of coronary events after myocardial infarction in patients with average cholesterol levels. Circulation, 98 (9): 839844, 1998.

42- TIETZ N.W.: Clinical guide to laboratory tests. Pbl. W.B. Saunders, Co., Philadelphia, pp. 509-512, 1995.

43- TEMPLE R.C., CLARK P.M. and HALES C.N.: Measurement of insulin secretion in typ9e II diabetes: Problems and pitfalls. Diabetic Medicine, 9 (6): 503-512, 1992.

44- MATTHEWS D.R., HOSKER J.P., RUDENSKI A.S., NAYLOR B.A. and TURNER R.C: Homeostasis model assessment: Insulin resistance and beta-cell function from fasting plasma glucose and insulin concentrations in man. Diabetologia., 28 (7): 412-9, 1985.

45- SUN G., BISHOP J., KHALILI S., VASDEV S., GILL V., PACE D., FITZPATRICK D., RANDELL E., YA-XIE G. and ZHANG H: Serum visfatin concentrations are positively correlated with serum triacylglycerols and down-regulated by overfeeding in healthy young men. Am. J. Clin. Nutr., 85: 399-404, 2007.

46- NAITO H.K.: Triglycerides in clinical chemistry: Theory, analysis and correlation. Pbl. KaplanL A. and Pesce A.J., U.S.A., pp. 997, 1989.

47- NAUK M., MARZ W. and JARAUSCH J.: Multicenter evaluation of homogenous assay for HDL-Cholesterol without sample pretreatment. Clin. Chem., 43 (9): 1622$1629,1997$.

48- FRIEDWALD W.T., LEVY R.I. and FREDRICKSON D.S.: Estimation of the concentration of low-density lipoprotein cholesterol in plasma, without use of the preparative ultracentrifuge. Clin. Chem., 18: 499-502, 1972.

49- MARTIN P.: A guide to laboratory animal technology, 2nd ed. Willim Uheine, medical box limited, London, p. 71,1981

50- QUICK A.J.: Hemorrhage disease and thrombosis. 9 ed. Lea and Febiger, Philadelphia. P209, 1966.

51- ARKIN C.: One stage PT and APTT. Approved Guide line., 16 (3) NCCLS, 1996.

52- ANSELL J.E.: Impression of prothrombin times monitoring of oral anticoagulants. Am. J. Clin. Path., 98: 237-239, 1992.

53- COOPER J. and DOUGLAS A.: Fibrinogen level as a Predictor of mortality in survivers of myocardial infarction. Fibrinolysis, 5: 105-108, 1991.

54- DECLERCK P.J., MOMBAERTS P., HOLVOET P., DEMOL M. and COLLEN D.: Fibrinolytic response and fibrin fragment $\mathrm{D}$-dimers in patients with deep venous thrombosis. Thromb. Haemost., 58: 1024-1029, 1987.

55- FISHER N.C., WILDE J.T., ROPER J. and ELIAS E.: Deficiency of natural anticoagulant proteins $C, S$, and antithrombin in portal vein thrombosis: A secondary phenomenon? Gut., 46: 534-539, 2000.

56- ASKARI H., SEIFI B., KADKHODAEE M., SANADGOL N., ELSHIEKH M., RANJBARAN M. and AHGHARI 
P.: Protective effects of hydrogen sulfide on chronic kidney disease by reducing oxidative stress, inflammation and apoptosis. EXCLI Journal, 17: 14-23, 2018.

57- ANTUNES S.A. and CANZIANI M.E.F.: Hepcidin: An important iron metabolism regulator in chronic kidney disease. J. Bras. Nefrol., 38 (3): 351-355, 2016.

58- VERGA FALZACAPPA M.V., VUJIC SPASIC M, KESSLER R., STOLTE J., HENTZE M.W. and MUCKENTHALER M.U.: STAT3 mediates hepatic hepcidin expression and its inflammatory stimulation. Blood, 109: 353-8, 2007.

59- NEMETH E., RIVERA S., GABAYAN V., et al.: IL-6 mediates hypoferremia of inflammation by inducing the synthesis of the iron regulatory hormone hepcidin. J. Clin. Invest., 113: 1271-6, 2004.

60- TANDARA L., ZANIC G.T., GUDELJ I., JURISIC Z., TANDARA M., GUGO K., MLADINOV S. and SALAMUNIC I.: Systemic inflammation up-regulates serum hepcidin in exacerbations and stabile chronic obstructive pulmonary disease. Clinical Biochemistry, 48 (18): 2015.

61- PAPANIKOLAOU G., TZILIANOS M., CHRISTAKIS J.I., et al.: Hepcidin in iron overload disorders. Blood, 105: 4103-5, 2005.

62- WRIGHTING D.M. and ANDREWS N.C.: Interleukin6 induces hepcidin expression through STAT3. Blood, 108: 3204-9, 2006.

63- KEMNA E., PICKKERS P., NEMETH E., VAN DER HOEVEN H. and SWINKELS D.: Time-course analysis of hepcidin, serum iron, and plasma cytokine levels in humans injected with LPS. Blood, 106: 1864-6, 2005.

64- HASHIZUME M, UCHIYAMA Y, HORAI N, et al.: A humanized anti-interleukin- 6 receptor antibody, improved anemia in monkey arthritis by suppressing IL-6-induced hepcidin production. Rheumatol. Int., 30: 917-923.119, 2010.

65- SONG S.N., TOMOSUGI N., KAWABATA H., et al.: Down-regulation of hepcidin resulting from long-term treatment with an anti-IL-6 receptor antibody (tocilizumab) improves anemia of inflammation in multicentric Castleman disease. Blood, 116: 3627-3634, 2010.

66- NKF-K/DOQI clinical practice guidelines for anemia of chronic kidney disease: Update 2000. Am. J. Kidney .Dis. 37 (Suppl 1): S182-S238, published erratum appears in Am. J. Kidney. Dis., 38: 442, 2001.

67- THOMAS WAYNE, HINCHLIFFE R.F., BRIGGS C., MACDOUGALL I.C. LITTLEWOOD T. and CAVILL I.: Guideline for the laboratory diagnosis of functional iron deficiency., British Journal of Haematology, 161: 639648D, 2013.

68- RUBAB Z., HUMA AMIN H., ABBAS K., HUSSAIN S., IKRAM M.U. and MOHSINET S.: Serum Hepcidin Levels in Patients with End-Stage Renal Disease on Hemodialysis., Saudi. J. Kidney. Dis. Transpl., 26 (1): 19-25, 2015.

69- GOYAL H., MOHANTY S., SHARMA M. and RANI A.: Study of anemia in nondialysis dependent chronic kidney disease with special reference to serum hepcidin. Indian J. Nephrol., 27: 44-50, 2017.
70- BABITT J.L. and LIN H.Y.: Molecular mechanisms of hepcidin regulation: implications for the anemia of CKD. Am. J. Kidney. Dis., 55 (4): 726-741, 2010.

71- BOCCARDO P., REMUZZI G. and GALBUSERA M.: Platelet dysfunction in renal failure. Semin Thromb Hemost., 30: 579-589, 2004.

72- MOHAMAD N.M. and ALSIDDIG B.: Estimation and assessment of protein c/s among Sudanese patients in Aljazeera state with chronic renal failure. International Journal of Information Research and Review, 2 (12): 1447 1449, 2015.

73- LAI K., YIN J.A., YUEN P.M.P., et al: Effect of hemodialysis on protein $\mathrm{C}$, protein $\mathrm{S}$ and antithrombin II levels. Am. J. Kidney. Dis., 17: 38-42, 1991.

74- MOLINO D., DE LUCIA D., MAROTTA R., PERNA A., LOMBARDI C., CIRILLO M. and de SANTO N.G.: In uremia, plasma levels of anti-protein $\mathrm{C}$ and anti-protein $\mathrm{S}$ antibodies are associated with thrombosis. Kidney. International, 68: 1223-1229, 2005.

75- VAN DER LOO B. and MARTIN J.F.: A Role for Changes in Platelet Production in the Cause of Acute Coronary Syndromes. Arterioscler. Thromb. Vasc. Biol., 19: 672679, 1999.

76- PAVORD S. and MYERS B.: Bleeding and thrombotic complications of kidney disease. Blood Rev., 25: 271 $278,2011$.

77- PARIKH A.M., SPENCER F.A., LESSARD D., et al.: Venous thrombo-embolism in patients with reduced estimated GFR: A population based perspective. Am. J. Kidney. Dis., 58: 746-755, 2011.

78- HRAFNKELSDÓ TTIR T., OTTOS SON P., GUDNASON T., SAMUELSSON O. and JERN S.: Impaired endothelial release of tissue-type plasminogen activator in patients with chronic kidney disease and hypertension. Hypertension, 44 (3): 300-304, 2004.

79- SECHI L.A., NOVELLO M., COLUSSI G., et al.: Relationship of plasma renin with a prothrombotic state in hypertension: Relevance for organ damage. Am. J. Hypertens, 21 (12): 1347-1353, 2008.

80- SEGARRA A., CHACÓN P., MARTINEZ-EYARRE C., et al.: Circulating levels of plasminogen activator inhibitor type-1, tissue plasminogen activator, and thrombomodulin in hemodialysis patients: Biochemical correlations and role as independent predictors of coronary artery stenosis. J. Am. Soc. Nephrol., 12 (6): 1255-1263, 2001.

81- PAWLAK K., TANKIEWICZ J., MYSLIWIEC M. and PAWLAK D.: Tissue factor/its pathway inhibitor system and kynurenines in chronic kidney disease patients on conservative treatment. Blood Coagul. Fibrinolysis., June 1, (Epub ahead of print), 2009.

82- MAL /YSZKO J., MALYSZKO J.S. and MYLIWIEC M.: Endothelial cell injury markers in chronic renal failure on conservative treatment and continuous ambulatory peritoneal dialysis. Kidney. Blood Press. Res., 27 (2): $71-$ 77, 2004.

83- MATSUO T., KOIDE M., KARIO K., SUZUKI S. and MATSUO M.: Extrinsic coagulation factors and tissue factor pathway inhibitor in end-stage chronic renal failure. Haemostasis, 27 (4): 163-167, 1997. 
84- CANTIN B., DESPRÉS J.P., LAMARCHE B., et al.: Association of fibrinogen and lipoprotein (a) as a coronary heart disease risk factor in men (The Quebec Cardiovascular Study). Am. J. Cardiol., 89 (6): 662-666, 2002.

85- CACHOFEIRO V., GOICOCHEA M., GARCIA DE VINUESA S., OUBINA P., LAHERA V. and LUNO J.: Oxidative stress and inflammation, a link between chronic kidney disease and cardiovascular disease. Kidney International., 74 (111): S4-S9, 2008.

86- MANOLOV V., YONOVA D., BOGOV B., PETROVA J., VASILEV V., VAZELOV E., GEORGIEVA I., TRENDAFILOV I., PAPAZOV V. and TZATCHEV K.: Hepcidin, Selenium and Superoxide Dismutase in Oxidative Stress and in Dialysis Patients. J. Urol. Nephrol., 2 (1): 000116, 2017.

87- LEE H.J., CHOI J.S., LEE H., WON-HOKIM, PARK and SONG J.: Effect of excess iron on oxidative stress and gluconeogenesis through hepcidin during mitochondrial dysfunction. The Journal of Nutritional Biochemistry, 26 (12): 1414-1423, 2015

88- CHEN J., MUNTNER P., HAMM L.L., FONSECA V., BATUMAN V., et al.: Insulin resistance and risk of chronic kidney disease in nondiabetic US adults. J. Am. Soc. Nephrol., 14: 469-477, 2003.

89- FRANKEL A.H. and KAZEMPOUR-ARDEBILI S.: Effect of Insulin Resistance in Chronic Kidney Disease. Endocrinol. Metab. Syndr., 5: 255, 2016.

90- ANDREWS M. and ARREDONDO M.: Association between ferritin, high sensitivity C-reactive protein (hsCRP) and relative abundance of hepcidin mRNA with the risk of type 2 diabetes in obese subjects. Nutr. Hosp., 30: 577584, 2014.

91- SAM A.H., BUSBRIDGE M., AMIN A., WEBBER L., WHITE D., FRANKS S., et al.: Hepcidin levels in diabetes mellitus and polycystic ovary syndrome. Diabet. Med., 30: 1495-1499, 2013.

92- SWAROOP J.J., RAJARAJESWARI D. and NAIDU J.N.: Association of TNF-alpha with insulin resistance in type 2 diabetes mellitus. Indian. J. Med. Res., 135: 127-30, 2012.

93- REHMAN K. and AKASH M.S.H.: Mechanisms of inflammatory responses and development of insulin resistance: How are they interlinked? Journal of Biomedical. Science, 23: 87-105, 2016.

94- DE DOMENICO I., ZHANG T.Y., KOENING C.L., BRANCH R.W., LONDON N., LO E., DAYNES R. A., KUSHNER J.P., LI D., WARD D.M. and KAPLAN J.: Hepcidin mediates transcriptional changes that modulate acute cytokine-induced inflammatory responses in mice. J. Clin. Invest., 120 (7): 2395-2405, 2010.

95- PAGANI A., NAI A., CORNA G., BOSURGI L., ROVERE-QUERINI P., CAMASCHELLA C. and SILVESTRI L.: Low hepcidin accounts for the proinflammatory status associated with iron deficiency. Blood, 118 (3): 736-746, 2011.

96- KHAN H.A. and OLA M.S.: Markers of blood coagulation, lipid profile, renal function test and serum electrolytes in streptozotocin-induced diabetic rats. Biomedical Research, 23 (3): 421-424, 2012.
97- VAZIRI N.D.: Dyslipidemia of chronic renal failure: The nature, mechanisms, and potential consequences. Am. J, Physiol, Renal, Physiol., 290: F262-72, 2006.

98- LUTZ J., MENKE J., SOLLINGER D., SCHINZE H. and THÜRMEL K.: Haemostasis in chronic kidney disease. Nephrol. Dial. Transplant., 29: 29-40, 2014.

99- VIGANO G., BENIGNI A., MENDOGNI D., et al.: Recombinant human erythropoietin to correct uremic bleeding. Am. J. Kidney. Dis., 18: 44-49, 1991.

100- KHEDR E., EL-SHARKAWY M., ABDULWAHAB S., Nor ELDIN E., ALI M., YOUSSIF A. and AHMED B.: Effect of recombinant human erythropoietin on insulin resistance in hemodialysis patients. Hemodialysis Inter national, 13: 340-346, 2009.

101- LAHERA V., GOICOECHEA M., GARCÍA DE VINUESA S., OUBIÑA P., CACHOFEIRO V., GÓMEZ-CAMPDERÁ F., AMANN R. and LUÑO J.: Oxidative Stress in Uremia: The Role of Anemia Correction. JASN, 17: S 174-S177, 2006.

102- ALKHAROUF J., NALINIKUMARI K., CORRY D. and TUCK M.: Long-term effects of the angiotensin converting enzyme inhibitor captopril on metabolic control in noninsulin dependent diabetes mellitus. Am. J. Hypertens, 6: 337-343, 1993.

103- GARCÍA DE VINUESA S., GOICOECHEA M., KANTER J., PUERTA M., CACHOFEIRO V., LAHERA V., GÓMEZ-CAMPDERÁ F. and LUÑO J.: Insulin Resistance, Inflammatory Biomarkers, and Adipokines in Patients with Chronic Kidney Disease: Effects of Angiotensin II Blockade. JASN, 17: S206-S212, 2006.

104- DILIP G.: Angiotensin-converting enzyme inhibitors in lipid metabolism and atherosclerosis: An ace up the sleeve? Journal of the Scientific Society, 41 (1): 59-60, 2014.

105- NANDEESHA H., PAVITHRAN P. and MADANMOHAN T.: Effect of antihypertensive therapy on serum lipids in newly diagnosed essential hypertensive men. Angiology, 60: 217-20, 2009.

106- EMEKLI-ALTURFANA E., ZDEMIRA G. SAGLAMB E., ZDAMARB E.N. and GKSELENERC Z.: Angiotensin-converting enzyme inhibitor captopril ameliorates renal damage in a rat model of thermal injury. Asian Biomedicine, 7 (3): 381-389, 2013.

107- MANNA M.J., ABU-RAGHIF A. and ABBOOD M.S.: Effect of Captopril on Inflammatory Biomarkers, Oxidative Stress Parameters and Histological Outcome in Experimental Induced Colitis. J. Pharm. Sci. \& Res., 9 (9): 1629-1636, 2017.

108- CHISI J.E., WDZIECZAK-BAKALA J., THIERRY J., BRISCOE C.V. and RICHES A.C.: Captopril inhibits the proliferation of hematopoetic stem and progenitor cells in murine long-term bone marrow cultures. Stem. Cells, 17: 339-44, 1999.

109- SICA D.A. and DEEDWANIA P.: ACE Inhibitors and Anemia in Congestive Heart Failure. CHF, 6: 330-332, 2000.

110-TARCAN A., GÜRAKAN B. and OZBEK N.: Captoprilinduced pancytopenia in a premature newborn. J. Paediatr. Child Health, 40: 404-405, 2004. 
111- AL-SHEIBANI B.I.: Effect of captopril and enalapril on selected coagulation markers in hyperlipidemia. QMJ, 2 (3): 107-116, 2007.
112- LAZAR H.L.: Role of Angiotensin-Converting Enzyme Inhibitors in the Coronary Artery Bypass Patient. Ann. Thorac. Surg., 79: 1081-9, 2005.

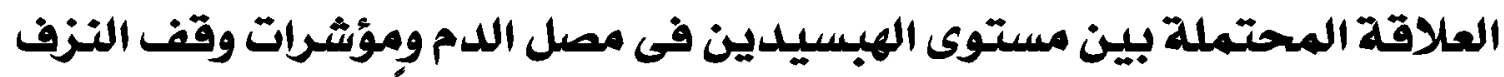

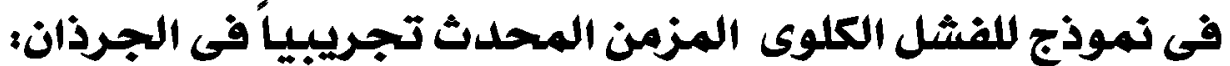 تأثير تثبيط الإنزيم الهحول للأنجيوتنسين الهوني}

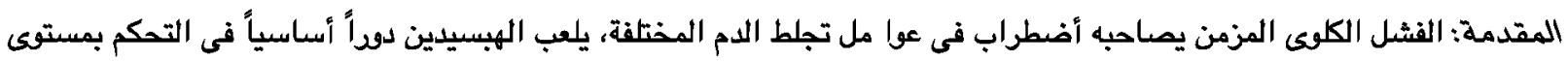

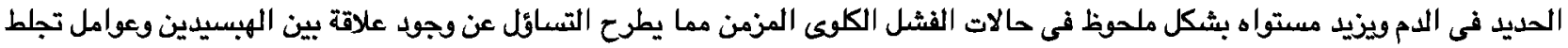

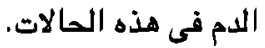

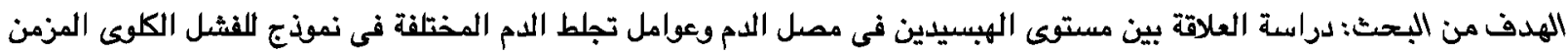
المحدث تجرييياً فى الجرذان ودراسة تأثير تناول عقار مثبط للأنزيم المحول للأنجيوتنسين ( كابتوبريل) على هذه العلاقة. طرق البحث: أجريت الدراسة على •ع من ذكور الجرذان البيضاء البالغة هقسمة إلى الجموعات التالية:

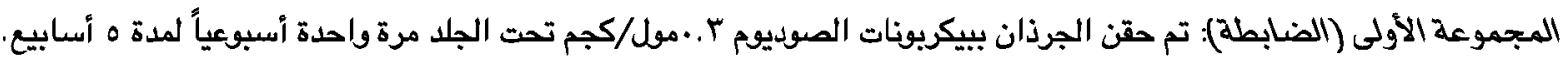

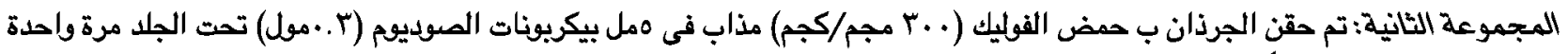

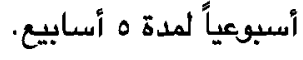

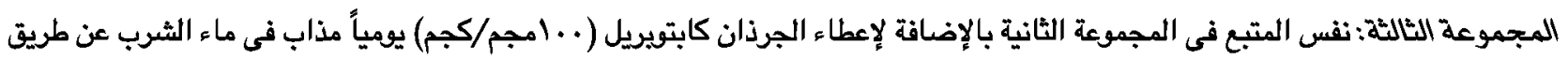

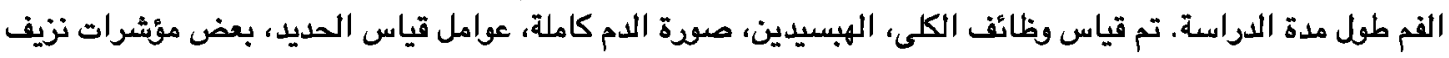

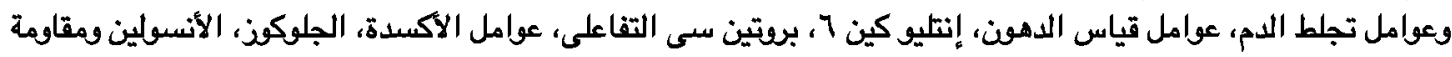

$$
\text { الأنسولين لجميع المجموعات. }
$$

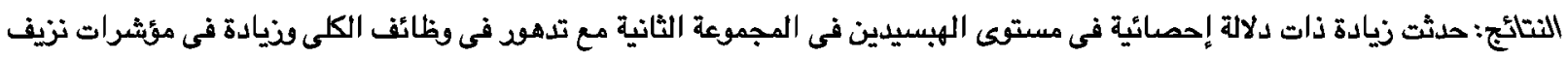

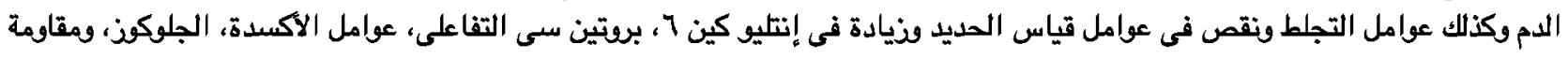

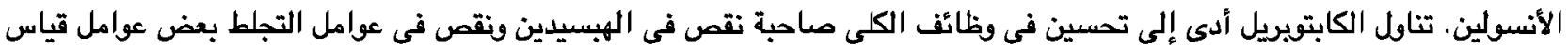

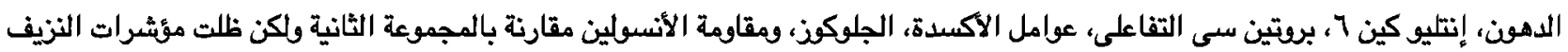
مرتفعة مقارنة بالمجموعة الضابطة،

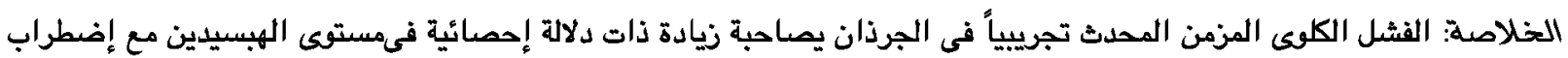

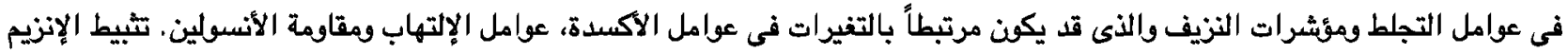

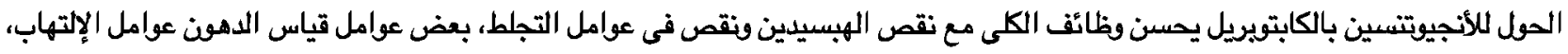
عوامل الأكسدة ومقاومة الأنسولين ولكن ظلت مؤشرات النزيل باتيف مرتفعة. 